\title{
BIOLOGICAL CONTROL OF RICE BROWN SPOT WITH NATIVE ISOLATES OF THREE TRICHODERMA SPECIES
}

\author{
Elham Khalili $^{1 *}$; Mehdi Sadravi ${ }^{2}$; Shahram Naeimi ${ }^{3}$; Vahid Khosravi ${ }^{4}$ \\ ${ }^{1}$ Department of Plant Pathology, Gorgan University of Agriculture Science and Natural Resources, Gorgan, Golestan, Iran; \\ ${ }^{2}$ Department of Plant Pathology, Yasouj University, Yasouj, Iran; ${ }^{3}$ Amol Biological Control Research Laboratory, Iranian \\ Research Institute of Plant Protection, Tehran, Iran; ${ }^{4}$ Deputy of Rice Research Institute in Mazandaran, Amol, Iran.
}

Submitted: January 09, 2011; Returned to authors for corrections: March 13, 2011; Approved: June 06, 2011.

\begin{abstract}
Brown spot caused by Bipolaris oryzae is an important rice disease in Southern coast of Caspian Sea, the major rice growing region in Iran. A total of 45 Trichoderma isolates were obtained from rice paddy fields in Golestan and Mazandaran provinces which belonged to Trichoderma harzianum, T. virens and T. atroviride species. Initially, they were screened against $B$. oryzae by antagonism tests including dual culture, volatile and nonvolatile metabolites and hyperparasitism. Results showed that Trichoderma isolates can significantly inhibit mycelium growth of pathogen in vitro by producing volatile and nonvolatile metabolites Light microscopic observations showed no evidence of mycoparasitic behaviour of the tested isolates of Trichoderma spp. such as coiling around the B. oryzae. According to in vitro experiments, Trichoderma isolates were selected in order to evaluate their efficacy in controlling brown spot in glasshouse using seed treatment and foliar spray methods. Concerning the glasshouse tests, two strains of T. harzianum significantly controlled the disease and one strain of $T$. atroviride increased the seedling growth. It is the first time that the biological control of rice brown spot and increase of seedling growth with Trichoderma species have been studied in Iran.
\end{abstract}

Key words: Rice brown spot, Biocontrol, Trichoderma harzianum, T. virens, T. atroviride

\section{INTRODUCTION}

Rice (Oryza sativa L.) is among the most important cereals in Iran. On the basis of nutrition value, it is comparatively rated more than other cereals and plays a key role in nutrition (1). Rice brown spot caused by Bipolaris oryzae Breda de Hann (formerly, Helminthosporium oryzae) (Teleomorph: Cochliobolus miyabeanus) is occurred in all rice-growing areas of the world. The pathogen causes infection on all growth stages of rice plant from nursery to field and results in significant yield and grain quality losses. Rice brown spot was a major factor for the "Great Bengal Famine" during 19421943 (27). In 1956, the disease was reported by Petrak at the first time from Iran and then it was reported by Sharif and Ershad from coastal area of Caspian sea in 1966 (16). The disease is prevalent in northern provinces of Iran and under environmental conditions conducive to disease; it can cause severe yield loss $(30,22)$.

Continuous, inappropriate and non-discriminative use of chemicals is known to cause undesirable effects such as residual toxicity, development of pathogen resistance to fungicides, environmental pollution, health hazards to humans

*Corresponding Author. Mailing address: MSc graduate student of Gorgan University of Agricultural Sciences and Natural Resources, Gorgan, Iran.; Tel: + 98 -171-4426432 Fax: + 98 - 171- 4426432.; E-mail: elham.khalili_2007@yahoo.com 
and animals and increased expenditure for plant protection. Instead, plant pathologists have focused their attention to develop environmentally safe, long-lasting and effective biocontrol methods for the management of plant diseases. Among various fungal and bacterial biocontrol agents, Trichoderma spp. was most frequently used against various plant diseases. Research during the previous two decades has led to the possibility of biological control as an increasingly realistic option for rice disease management (32). Trichoderma spp. has been shown to be effective for the control of brown spot disease and the increase of plant growth on rice (17). Rice plants sprayed with spore suspension of T. harzianum obtained a significant reduction in the severity of disease under greenhouse conditions (2). Also, Trichoderma species are able to colonize the root surface and rhizosphere from the treated seeds, protecting them from fungal diseases and stimulate plant growth and productivity (4). This study was accomplished to obtain indigenous Trichoderma isolates from paddy fields and to examine their biocontrol activities against $B$. oryzae in vitro as well as in vivo and also to evaluate their effects on rice growth parameters.

\section{MATERIALS AND METHODS}

\section{Fungal isolates}

In order to isolate Trichoderma spp., phyllosphere and soil samples were collected from paddy fields in Mazandaran and Golestan provinces from March to August 2007. Soil samples were taken at 0-30 cm depth. Isolation of Trichoderma from soil samples was performed by the soil dilution method (21). Ten grams of each soil sample was added to $90 \mathrm{~mL}$ distilled water on a shaker for one hour. Then, $10 \mathrm{mLaliquot}$ from this suspension was transferred aseptically to $90 \mathrm{~mL}$ distilled water. This dilution process was repeated to get dilutions up to $10^{-5}$. In the case of phyllosphere samples, rice stems and leaves were cut into $5 \mathrm{~mm}$ pieces and added to 150 $\mathrm{mL}$ distilled water on a shaker for 30 minutes. From each dilution suspension, one millilitre of aliquots (from soil and phyllosphere sample) was spread on RB-S-F selective medium
(9) in $9 \mathrm{~cm}$ Petri dishes. The dishes were incubated at $26 \pm 1^{\circ} \mathrm{C}$ in the dark for 3-4 days. Putative Trichoderma isolates were purified using single spore technique.

For isolation of pathogen, naturally diseased leaves of different rice cultivars infected with varying degrees of brown spot were collected from nurseries and fields at different geographic locations in Mazandaran province, Iran. Eight $B$. oryzae isolates were obtained and purified using single spore technique $(15,30)$. For pathogenicity test 21-day-old rice seedlings of the most common cultivar in north of Iran $i$. $e$. Tarom, were grown under greenhouse conditions, and sprayed with spore suspension $\left(4 \times 10^{5}\right.$ spore $\left.\mathrm{mL}^{-1}\right)$ of each $B$. oryzae isolate. Seven days after inoculation, the severity of brown spot disease was assessed following the standard evaluation system of International Rice Research Institute (20). The most aggressive $B$. oryzae isolate was selected for in vitro and in vivo tests of this study.

\section{Identification of Trichoderma isolates}

For morphological identification, Trichoderma isolates were grown on $2 \%$ malt extract agar under ambient laboratory conditions of light and temperature (about $21^{\circ} \mathrm{C}$ ). Microscopic examination was carried out by mounting the culture in lactic acid $25 \%$. Individual isolates were identified at the species level using morphological keys and fungal species descriptions $(5,6,13,35)$. For molecular identification, a nuclear rDNA region, containing the internal transcribed spacers 1 and 2 (ITS1 and 2) and the 5.8S rRNA gene was amplified using the primers ITS1 and ITS4 (34). PCR amplifications were performed as described previously (19). Amplicons were purified with the GenElute PCR Clean-up Kit (Sigma, USA) and sequenced at Macrogen Inc., South Korea. In order to identify the isolates at the species level, ITS sequence analysis was carried out with the aid of the program TrichOkey 2.0 available online at http://www.isth.info/.

\section{In vitro antagonism tests}

Dual culture: Nine centimetres Petri plates containing potato dextrose agar (PDA) were inoculated with $5 \mathrm{~mm}$ 
mycelial disks of either B. oryzae and Trichoderma isolates 10 $\mathrm{mm}$ away from the edge of the plate opposite to each other. Plates inoculated with $B$. oryzae alone served as control. Plates were incubated at $26 \pm 1^{\circ} \mathrm{C}$ for seven days $(12 \mathrm{~h} \mathrm{light} / 12 \mathrm{~h}$ darkness). The linear growth was measured. Three replicate plates were done for each treatment. The percentage of growth inhibition was calculated using the equation $\mathrm{RI}=100 \times(\mathrm{R} 2-$ R1) / R2. Where RI was the percentage of reduction in mycelial growth, R1 was the averaged growth of pathogen in treated plates and R2 was the averaged growth of pathogen in control plates (12).

Production of volatile compounds: The bottoms of Petri dishes containing PDA were separately inoculated with mycelial plugs of pathogen and Trichoderma isolates. Then two bottoms held together with pathogen at top, sealed with adhesive tape and incubated at $26 \pm 1^{\circ} \mathrm{C}$ in the dark for seven days. The radial growth of the pathogens was measured. Three replicates of each treatment were used (11).

Production of non-volatile compounds: A piece of autoclaved cellophane was placed on the surface of PDA medium in a $9 \mathrm{~cm}$ plate then a $7 \mathrm{~mm}$ disk of Trichoderma isolate was inoculated on the cellophane. The plates were incubated at $26 \pm 1{ }^{\circ} \mathrm{C}$ for $72 \mathrm{~h}$. After the incubation period, the cellophane and the adhering Trichoderma mycelia were aseptically removed and the centre of each dish was inoculated with a $5 \mathrm{~mm}$ diameter disk of $B$. oryzae taken from an actively growing colony. The plates were incubated at $26 \pm 1{ }^{\circ} \mathrm{C}$ for a further five days. The control treatment was B. oryzae grown on PDA plate where previously there was a cellophane disc without antagonist. Three replicate plates were done for each treatment. The percentage of growth inhibition was calculated (12).

Mycoparasitism test: The slide culture method (28) was used to investigate the mycoparasitic nature of Trichoderma isolates against $B$. oryzae. A microscope glass slide covered with a thin layer of PDA in the agar plate was inoculated with
$5 \mathrm{~mm}$ mycelial disks of Trichoderma spp. and pathogen, $1 \mathrm{~cm}$ apart from each other. All paired cultures incubated at $26{ }^{\circ} \mathrm{C}$ and regions where the hyphae of Trichoderma isolates met the hyphae of the pathogen were periodically observed under a light microscope.

\section{Evaluation of Trichoderma isolates on wet filter paper:}

Based on in vitro antagonism test, 20 Trichoderma isolates were selected. Rice seeds were soaked in spore suspension of B. oryzae $\left(10^{5}\right.$ spores $\left.\mathrm{mL}^{-1}\right)$ containing $0.05 \%$ Tween 20 for 24 h. Then, seeds were air-dried and soaked in spore suspension of Trichoderma isolates $\left(10^{8}\right.$ spores $\left.\mathrm{mL}^{-1}\right)$ containing $0.05 \%$ Tween 20 for $2 \mathrm{~h}$ and then placed on the sterile wet filter paper in a seedling tray with 100 seeds per treatment (7). Plant height, root length and the percentage of disease control were determined. The number of infected seedlings was counted for each treatment and then compared to infected control with $B$. oryzae.

\section{Glasshouse experiments}

Seed treatment: According to wet filter paper test, 11 Trichoderma isolates were selected and used to inoculate infested rice seeds with pathogen and were sown in plastic pots containing autoclaved rice field soil. The pots were kept in glasshouse with the condition of 21 to $30^{\circ} \mathrm{C}$ temperature and $90 \%$ relative humidity. Three pots were used for each treatment. Rice seedlings growth parameters namely stem height, root length, stem and root wet weight, stem and root dry weight and percentage of disease control were determined 45 days after inoculation. Rice stem and root were dried in an oven at $80^{\circ} \mathrm{C}$ for 24 hours to a dry weight.

Foliar spray

Twenty one days old rice seedlings (cv. Tarom) were sprayed with spore suspension of 11 selected Trichoderma isolates $\left(10^{8}\right.$ spore $\left.\mathrm{mL}^{-1}\right)$ with $0.05 \%$ Tween 20 in greenhouse. After $24 \mathrm{~h}$, the plants were sprayed with the spore suspension of $B$. oryzae $\left(10^{5}\right.$ spore $\left.\mathrm{mL}^{-1}\right)$. The seedlings which were sprayed with $B$. oryzae alone, served as control. Observations on the disease severity were recorded seven days after 
inoculation of pathogen and the percentage of disease control was calculated for each individual treatment (12). The completely randomized design with three replications (pots) and five seedlings per pot was used.

\section{Statistical analysis}

The completely randomized design with three replications per treatment was used. Data were analyzed with statistical analysis software (6.0 SAS, 1999). All data were first subjected to analysis of variance (ANOVA). Means were compared using Duncan's multiple range test at $\mathrm{P}=0.01$.

\section{RESULTS}

A total of 45 Trichoderma isolates were obtained which belonged to three species namely Trichoderma harzianum, $T$. virens and $T$. atroviride. The percentage of the total Trichoderma isolates obtained from the rice phyllosphere and soil samples were 63 and 38 percent, respectively. The most frequent species was $T$. harziunum with 31 isolates $(69 \%)$. Eleven and three isolates belonged to $T$. virens and $T$. atroviride, respectively.

Based on the pathogenicity test, B. oryzae 3 (from a rice field in Amol, Mazandaran) showed highest disease severity, and this most aggressive isolate was used for all subsequent studies.

Data from dual culture tests showed that although all 45 Trichoderma isolates inhibited the mycelium growth of pathogen, there were significant differences among them at $\mathrm{P}=0.01 . T$. harzianum isolates 38, 4, 27, 35, 20 and 7; T. virens isolates 8 and 13 and T. atroviride isolate 3 substantially reduced the growth of the pathogen (Table 1).

Table 1. In vitro effects of Trichoderma isolates on mycelial growth of Bipolaris oryzae.

\begin{tabular}{|c|c|c|c|}
\hline \multicolumn{3}{|c|}{ The percentage of reduction in mycelial growth } & \multirow[b]{2}{*}{ Isolates } \\
\hline Non-volatile metabolite & Volatile metabolite & Dual culture & \\
\hline $84.5 \mathrm{~b}$ & $70.2 \mathrm{abcd}$ & 69.1 cdef & T. harzianum 1 \\
\hline $52.7 \mathrm{qr}$ & 64.8 cdefg & $76.6 \mathrm{abcd}$ & T. harzianum 4 \\
\hline $56.0 \mathrm{pq}$ & $70.7 \mathrm{abc}$ & 70.0 cdef & T. harzianum 6 \\
\hline 74.3 cde & $72.4 \mathrm{ab}$ & 71.9 abcde & T. harzianum 7 \\
\hline $70.8 \mathrm{efg}$ & 65.5 abcdefg & $54.4 \mathrm{ijk}$ & T. harzianum 9 \\
\hline $100.0 \mathrm{a}$ & 61.0 bcdefghi & $50.8 \mathrm{ijk}$ & T. harzianum 10 \\
\hline $61.8 \mathrm{lmn}$ & 67.7 abcde & $53.2 \mathrm{ijk}$ & T. harzianum 11 \\
\hline $100.0 \mathrm{a}$ & 56.3 efghijk & 64.4 efgh & T. harzianum 15 \\
\hline 58.2 nop & 61.0 bcdefghi & 66.3 efgh & T. harzianum 19 \\
\hline $70.2 \mathrm{efg}$ & $43.6 \mathrm{~lm}$ & 71.9 abcde & T. harzianum 20 \\
\hline $63.6 \mathrm{klm}$ & $47.1 \mathrm{jkl}$ & 65.4 efgh & T. harzianum 21 \\
\hline 74.4 cde & 65.2 abcdefg & $68.2 \mathrm{def}$ & T. harzianum 22 \\
\hline $73.0 \mathrm{def}$ & 63.3 abcdefgh & 71.0 bcdef & T. harzianum 23 \\
\hline $60.7 \mathrm{mno}$ & 63.3 abcdefgh & 69.1 cdef & T. harzianum 24 \\
\hline $76.9 \mathrm{~cd}$ & $69.0 \mathrm{abcd}$ & 57.9 hij & T. harzianum 26 \\
\hline 65.4 hijkl & $69.9 \mathrm{abcd}$ & 71.9 abcde & T. harzianum 27 \\
\hline $76.1 \mathrm{~cd}$ & 56.6 defghijk & $67.2 \mathrm{efg}$ & T. harzianum 28 \\
\hline $63.0 \mathrm{klm}$ & 58.5 cdefghij & 64.4 efgh & T. harzianum 29 \\
\hline 74.0 cde & 60.4 bcdefghi & 66.4 efgh & T. harzianum 30 \\
\hline $72.9 \mathrm{def}$ & 53.8 fghijkl & 66.3 efgh & T. harzianum 31 \\
\hline $48.8 \mathrm{r}$ & 64.6 abcdefgh & $67.2 \mathrm{efg}$ & T. harzianum 32 \\
\hline 57.4 op & 65.8 abcdef & 65.4 efgh & T. harzianum 33 \\
\hline 65.4 hijkl & 67.1 abcde & 71.9 abcde & T. harzianum 35 \\
\hline 69.0 fghi & 63.9 abcdefgh & $68.2 \mathrm{def}$ & T. harzianum 36 \\
\hline 73.9 cde & 63.9 abcdefgh & 69.1 cdef & T. harzianum 37 \\
\hline $69.3 \mathrm{fgh}$ & 52.5 hijkl & $79.4 \mathrm{a}^{*}$ & T. harzianum 38 \\
\hline $63.9 \mathrm{jklm}$ & $46.8 \mathrm{jkl}$ & 65.4 efgh & T. harzianum 40 \\
\hline $67.9 \mathrm{ghij}$ & 60.1 cdefghi & 64.4 efgh & T. harzianum 42 \\
\hline $65.0 \mathrm{ijkl}$ & 30.9 on & $68.2 \mathrm{def}$ & T. harzianum 43 \\
\hline $62.8 \mathrm{klm}$ & 64.5 abcdefgh & $68.2 \mathrm{def}$ & T. harzianum 44 \\
\hline $51.4 \mathrm{r}$ & 58.4 defghij & 65.4 efgh & T. harzianum 45 \\
\hline $100.0 \mathrm{a}$ & 53.4 ghijkl & $50.3 \mathrm{jk}$ & T. virens 2 \\
\hline $100.0 \mathrm{a}$ & $35.8 \mathrm{mn}$ & $58.9 \mathrm{ghi}$ & T. virens 5 \\
\hline $100.0 \mathrm{a}$ & $46.2 \mathrm{klm}$ & $77.5 \mathrm{abc}$ & T. virens 8 \\
\hline $100.0 \mathrm{a}$ & 54.4 fghijkl & $52.2 \mathrm{ijk}$ & T. virens 12 \\
\hline $100.0 \mathrm{a}$ & $50.9 \mathrm{ijkl}$ & 71.9 abcde & T. virens 13 \\
\hline
\end{tabular}




\begin{tabular}{|c|c|c|c|}
\hline $77.6 \mathrm{c}$ & 54.1 fghijkl & $62.6 \mathrm{fgh}$ & T. virens 14 \\
\hline $76.9 \mathrm{~cd}$ & 66.7 abcde & $50.8 \mathrm{ijk}$ & T. virens 16 \\
\hline $69.7 \mathrm{fg}$ & 56.6 efghijk & $53.2 \mathrm{ijk}$ & T. virens 18 \\
\hline $76.6 \mathrm{~cd}$ & 56.6 efghijk & $66.3 \mathrm{efgh}$ & T. virens 25 \\
\hline 66.6 ghijk & $22.1 \mathrm{o}$ & 59.0 ghi & T. virens 39 \\
\hline $100.0 \mathrm{a}$ & 62.6 bcdefghi & $66.3 \mathrm{efgh}$ & T. virens 41 \\
\hline $42.6 \mathrm{~s}$ & $21.8 \mathrm{o}$ & $78.4 \mathrm{ab}$ & T. atroviride 3 \\
\hline $64.9 \mathrm{ijklm}$ & 66.7 abcde & $48.5 \mathrm{k}$ & T. atroviride 17 \\
\hline $100.0 \mathrm{a}$ & $75.0 \mathrm{a}$ & $69.1 \mathrm{cdef}$ & T. atroviride 34 \\
\hline
\end{tabular}

Volatile metabolites of Trichoderma isolates also had inhibitory effects on the growth of $B$. oryzae. The most effective isolates were $T$. harzianum 4, 27, 35, 7, 23, 6, 24, 37, 1, 22, 44, 36, 32, 33, 26, 9 and 11; T. virens 16 and $T$. atroviride 34 and 17 (Table 1).

All tested Trichoderma isolates released non-volatile compounds that diffused through the cellophane membrane onto the agar medium, resulting inhibition growth of pathogen. The highest reduction in the mycelial growth of the pathogen (100\%) was recorded for T. harzianum 15 and 10; T. virens 8, 13, 41, 5, 12, 2 and T. atroviride 34 (Table 1).
Light microscopic observations showed no evidence of mycoparasitic behaviour of the tested isolates of Trichoderma spp. such as coiling around the $B$. oryzae.

In wet filter paper test, significant differences were observed in plant height, root length and the percentages of disease control between treated and untreated rice seeds. The highest disease control was recorded for $T$. harzianum $7,4,1$, 43, 38, 23, and 28; T. atroviride 17 and 3. Furthermore, T. harzianum isolates $7,4,43,38,23,28,27,22,20,32$, and $T$. virens isolate 8 showed increasing effects on the rice seedling growth (Table 2).

Table 2. Effect of Trichoderma isolates in controlling brown spot as well as on growth factors of rice seedlings in wet filter paper test.

\begin{tabular}{|c|c|c|c|}
\hline Isolates & Disease control (\%) & Stem height $(\mathrm{cm})$ & root length $(\mathrm{cm})$ \\
\hline T. harzianum 1 & $59.0 \mathrm{ab}$ & 5.7 bcdefg & $5.1 \mathrm{abcd}$ \\
\hline T. harzianum 4 & $60.3 \mathrm{a}$ & $6.6 \mathrm{abc}$ & $5.3 \mathrm{abc}$ \\
\hline T. harzianum 7 & $60.8 * \mathrm{a}$ & $6.6 \mathrm{ab}$ & $5.5 \mathrm{ab}$ \\
\hline T. harzianum 20 & $40.2 \mathrm{efgh}$ & $6.7 \mathrm{ab}$ & $5.8 \mathrm{a}$ \\
\hline T. harzianum 22 & 41.2 defgh & $6.4 \mathrm{abcd}$ & $5.7 \mathrm{a}$ \\
\hline T. harzianum 23 & 52.7 abcd & $6.6 \mathrm{abc}$ & $5.1 \mathrm{abcd}$ \\
\hline T. harzianum 24 & $22.2 \mathrm{j}$ & 5.4 bcdefg & 4.3 cde \\
\hline T. harzianum 27 & $45.2 \mathrm{cdef}$ & $7.5 \mathrm{a}$ & $4.2 \mathrm{cde}$ \\
\hline T. harzianum 28 & $52.2 \mathrm{abcd}$ & $7.3 \mathrm{a}$ & $4.0 \mathrm{e}$ \\
\hline T. harzianum 32 & 35.7 fghi & $6.4 \mathrm{abcd}$ & 4.5 bcde \\
\hline T. harzianum 35 & 46.0 cdef & 5.3 cdefg & 4.8 abcde \\
\hline T. harzianum 36 & 43.6 cdefg & 5.9 bcdef & 4.4 cde \\
\hline T. harzianum 37 & $26.0 \mathrm{ij}$ & $5.2 \mathrm{defg}$ & $5.1 \mathrm{abcd}$ \\
\hline T. harzianum 38 & $54.8 \mathrm{abc}$ & $7.5 \mathrm{a}$ & 4.5 bcde \\
\hline T. harzianum 43 & $58.2 \mathrm{ab}$ & $6.7 \mathrm{ab}$ & $5.5 \mathrm{ab}$ \\
\hline T. harzianum 44 & $31.5 \mathrm{hij}$ & $6.7 \mathrm{ab}$ & $4.3 \mathrm{cde}$ \\
\hline T. virens 2 & $33.5 \mathrm{ghi}$ & 5.4 bcdefg & 4.4 cde \\
\hline T. virens 8 & 35.9 fghi & 6.2 abcde & $5.1 \mathrm{abcd}$ \\
\hline T. virens 13 & 47.8 bcde & 5.8 bcdef & 5.0 abcde \\
\hline T. atroviride 3 & 50.0 abcde & $5.2 \mathrm{defg}$ & $5.1 \mathrm{abcd}$ \\
\hline T. atroviride 17 & 50.7 abcde & $5.0 \mathrm{efg}$ & 4.8 abcde \\
\hline T. atroviride 34 & 48.0 bcde & $4.5 \mathrm{~g}$ & $4.1 \mathrm{ed}$ \\
\hline $\begin{array}{l}\text { Inoculated control(with } \\
\text { B. oryzae) }\end{array}$ & - & $4.8 \mathrm{fg}$ & $5.1 \mathrm{abcd}$ \\
\hline Non-inoculated control & & 5.9 bcdef & $5.5 \mathrm{ab}$ \\
\hline
\end{tabular}


Seed treatment with Trichoderma isolates significantly decreased rice brown spot in glasshouse. T. harzianum 1 and 20 were the most effective isolates. In the case of growth factors, highest values were recorded for $T$. atroviride isolate 3 (Table 3 ).
Foliar spray with selected Trichoderma isolates in glasshouse showed that all treatments were significantly different in controlling the disease and T. harzianum 20 was the most effective isolate (Table 4).

Table 3. Effects of treatment of rice seeds by selected Trichoderma isolates on brown spot and growth characteristics of rice seedlings in glasshouse *.

\begin{tabular}{|c|c|c|c|c|c|c|c|}
\hline $\begin{array}{l}\text { Root dry } \\
\text { weight (g) }\end{array}$ & $\begin{array}{l}\text { Stem dry } \\
\text { weight (g) }\end{array}$ & $\begin{array}{l}\text { Root wet } \\
\text { weight (g) }\end{array}$ & $\begin{array}{l}\text { Stem wet } \\
\text { weight (g) }\end{array}$ & $\begin{array}{l}\text { Root length } \\
(\mathrm{cm})\end{array}$ & $\begin{array}{l}\text { Stem height } \\
(\mathrm{cm})\end{array}$ & $\begin{array}{l}\text { Disease } \\
\text { control }(\%)\end{array}$ & Isolate \\
\hline $0.2 \mathrm{e}$ & $0.2 \mathrm{f}$ & 0.8 ghi & $1.1 \mathrm{fgh}$ & $16.7 \mathrm{a}$ & $48.4 \mathrm{de}$ & $61.2 \mathrm{a}$ & T. harzianum 1 \\
\hline $0.5 \mathrm{bc}$ & $0.4 \mathrm{bcd}$ & $2.0 \mathrm{ab}$ & $2.3 \mathrm{~b}$ & $18.1 \mathrm{a}$ & $65.4 \mathrm{abcd}$ & 32.3 dce & T. harzianum 4 \\
\hline $0.4 \mathrm{c}$ & 0.3 bcde & $1.2 \mathrm{defg}$ & 1.4 defg & $19.8 \mathrm{a}$ & 53.2 abcde & $45.3 \mathrm{bc}$ & T. harzianum 7 \\
\hline $0.2 \mathrm{e}$ & $0.2 \mathrm{f}$ & $0.7 \mathrm{hi}$ & $0.9 \mathrm{gh}$ & $16.6 \mathrm{a}$ & $46.5 \mathrm{e}$ & $58.1 \mathrm{a}$ & T. harzianum 20 \\
\hline $0.4 \mathrm{~cd}$ & $0.4 \mathrm{bc}$ & $1.3 \mathrm{def}$ & $1.9 \mathrm{bcd}$ & $20.6 \mathrm{a}$ & $67.1 \mathrm{abc}$ & $20.8 \mathrm{e}$ & T. harzianum 27 \\
\hline $0.3 \mathrm{e}$ & 0.3 bcde & $0.5 \mathrm{i}$ & $0.8 \mathrm{~h}$ & $17.8 \mathrm{a}$ & 54.7 abcde & $50.3 \mathrm{ab}$ & T. harzianum 28 \\
\hline $0.4 \mathrm{~cd}$ & $0.4 \mathrm{ab}$ & $1.6 \mathrm{bcd}$ & $2.1 \mathrm{bc}$ & $17.9 \mathrm{a}$ & $68.0 \mathrm{ab}$ & $34.7 \mathrm{~cd}$ & T. atroviride 34 \\
\hline $0.3 \mathrm{de}$ & $0.3 \mathrm{def}$ & $1.2 \mathrm{defg}$ & $1.2 \mathrm{efgh}$ & $17.3 \mathrm{a}$ & 50.3 cde & $44.7 \mathrm{bc}$ & T. harzianum 38 \\
\hline $0.6 \mathrm{a}$ & 0.3 bcde & $1.8 \mathrm{bc}$ & $1.7 \mathrm{cde}$ & $17.5 \mathrm{a}$ & 60.5 abcde & $34.6 \mathrm{~cd}$ & T. harzianum 43 \\
\hline $0.3 \mathrm{de}$ & 0.3 bcde & $1.1 \mathrm{efgh}$ & 1.4 defg & $19.6 \mathrm{a}$ & 53.2 abcde & $39.4 \mathrm{bc}$ & T. virens 8 \\
\hline $0.6 \mathrm{ab}$ & $0.5 \mathrm{a}$ & $2.3 \mathrm{a}$ & $3.0 \mathrm{a}$ & $20.4 \mathrm{a}$ & $69.6 \mathrm{a}$ & $24.0 \mathrm{de}$ & T. atroviride 3 \\
\hline $0.2 \mathrm{e}$ & $0.2 \mathrm{fe}$ & $1.0 \mathrm{fgh}$ & $1.2 \mathrm{efgh}$ & $15.8 \mathrm{a}$ & 50.3 cde & & $\begin{array}{l}\text { Infected check } \\
\text { (with } B . \text { oryzae) }\end{array}$ \\
\hline $0.4 \mathrm{c}$ & 0.3 bcde & $1.5 \mathrm{cde}$ & $1.6 \mathrm{cdef}$ & $17.0 \mathrm{a}$ & 59.2 abcde & & Healthy check \\
\hline
\end{tabular}

* Values within a column followed by the same letter(s) are not significantly different according to Duncan's multiple range test $(\mathrm{P}=0.01)$

* Each value represents the mean of three replicates.

Table 4. Control of rice brown spot after foliar spray of Trichoderma isolates on Tarom cultivar*.

\begin{tabular}{ll}
\hline Treatment & Disease control (\%) \\
\hline$T$. harzianum 1 & $48.9 \mathrm{~b}$ \\
$T$. harzianum 4 & $35.0 \mathrm{ef}$ \\
T. harzianum 7 & $44.7 \mathrm{bcd}$ \\
$T$. harzianum 20 & $59.6 \mathrm{a}$ \\
$T$. harzianum 27 & $32.2 \mathrm{f}$ \\
$T$. harzianum 28 & $38.7 \mathrm{cdef}$ \\
$T$. atroviride 34 & $43.6 \mathrm{bcde}$ \\
$T$. harzianum 38 & $46.1 \mathrm{bcd}$ \\
$T$. harzianum 43 & $37.4 \mathrm{def}$ \\
$T$. virens 8 & $T$. virens 8 \\
$T$. atroviride 3 & T. atroviride 3 \\
\hline
\end{tabular}

* Values within a column followed by the same letter(s) are not significantly different according to

Duncan's multiple range test $(\mathrm{P}=0.01)$

*Each value represents the mean of three replicates.

\section{DISCUSSION}

The majority of isolates $(90 \%)$ recovered from the soil identified as $T$. harzianum and $T$. virens which is in agreement with the findings of Naeimi et al. (25). In addition, fungal species belonging to the genus Trichoderma are worldwide in occurrence and they have been widely reported from rice fields in other countries such as Philippine, China and Bangladesh $(23,26,36,29)$. The results of the present study showed that the Trichoderma isolates could easily adopt and survive in irrigated rice ecosystems of northern Iran and this gives hope for future application of the promising native strains in paddy 
fields in order to control brown spot and other rice diseases.

In vitro antagonism tests revealed that the native isolates of Trichoderma spp. significantly inhibited the mycelial growth of $B$. oryzae in several ways. The most effective isolates were belonged to $T$. harzianum. It is clear from the previous results that competition plays an important role in the $T$. harzianum and $B$. oryzae interaction $(2,17)$. Trichoderma isolates inhibited the growth of the target organisms through its ability to grow much faster than the pathogenic fungi thus competing efficiently for space and nutrients. Angelica et al. (3) reported that inhibition of pathogen growth is due to production of amylase by Trichoderma spp., which is partially responsible for the rapid growth of antagonists on potato dextrose agar medium. In addition to amylase, it has been reported that Trichoderma species also produce extracellular cellulose and pectinase enzymes that are capable of hydrolyzing the cell walls of other fungi (24). A comparison between the inhibition effects of volatile and nonvolatile metabolites of our Trichoderma isolates revealed that the nonvolatile metabolites seemed to be more effective. In a similar study, Abdel-Fattah et al. (2) also reported that the antifungal metabolites of $T$. harzianum strains completely inhibited the linear growth of $B$. oryzae. Gary et al. (14) identified five classes of volatile compounds, such as alcohols, esters, ketones, acids and lipids, produced by some fungi and bacteria. A large number of volatile and non-volatile antifungal substances such as diterpenes, peptaibols, butenolides, furanones, pyrones, and pyridones are produced by $T$. harzianum which have stimulus influence on plant growth and development. Trichoderma antifungal substances are also able to arrest the hyphal growth of different fungal pathogens. It is believed that these enzymes and antibiotics act synergistically on the host (8).

Light microscopic observations revealed that mycoparasitism did not appear to contribute to the aggressive nature of our Trichoderma isolates against B. oryzae which is in agreement with the findings of Abdel-Fattah et al. (2).

Results from seed treatments and foliar spray, demonstrated that significant reduction in disease severity is observed when $T$. harzianum 1 and 20 were applied in glasshouse. In addition, Trichoderma atroviride isolate 3 had substantial influence on plant growth and development. Similarly, Harish et al. (17) stated that spraying of spore suspension of Trichoderma isolates on rice plant significantly inhibited the growth and spore germination of $B$. oryzae besides increasing seedling growth. There are high levels of nutrients in the rhizosphere and pathogen and the introduced biocontrol agent (antagonist) compete for the availability of space and nutrients. Trichoderma spp. has been reported to be more rhizosphere competent than most soil fungi (32). Abundant production and germination of conidia by Trichoderma spp. and their rapid mycelial growth may suppress the growth of the pathogen population in the rhizosphere and thus reduce disease development. Promotion of plant growth induced by Trichoderma spp. appeared to be due to both the control of minor pathogens and production of growth-regulating factors. A number of plant-associated microbes were found to produce poisonous compound cyanide which causes reduction of the plant growth. Trichoderma spp. could produce enzymes which detoxify waste cyanide and this process lead to increase in plant growth. Recent advances demonstrate that the effects of Trichoderma on plants, including induced systemic or localized resistance, are also very important. These fungi colonize the root epidermis and outer cortical layers and release bioactive molecules that cause to induction of pathways for resistance in plants, increased plant growth and nutrient uptake occurs $(4,188)$.

This study has demonstrated that a number of naturally occurring fungal isolates can inhibit growth of $B$. oryzae. Furthermore, this research raises some interesting possibilities for future research. These include testing whether the antagonist can show the same level of efficacy under natural field conditions; testing whether mixtures of biocontrol agents are more effective than a single strain on control of disease severity and testing for preparing the best formulation of promising Trichoderma isolates.

\section{ACKNOWLEDGMENTS}

We would like to express our special thanks to the 
Department of Microbiology, Faculty of Sciences and Informatics, University of Szeged, Hungary for molecular identification of Trichoderma isolates.

\section{REFERENCES}

1. Alinia, F.; Bahrami, M.; Amoogholi-Tabari, M. (2002). Rice Significant Pests and Diseases and Their Control Methods. Jihad Agriculture Organization of Mazandaran Publications, Iran.

2. Abdel-Fataah, G.M.; Shabana, Y.M.; Ismail, A.E.; Rashad, Y.M. (2007). Trichoderma harzianum: a biocontrol agent against Bipolaris oryzae. Mycopathol. 164, 81-99.

3. Angelica, M.; Barbosa, G.; Rehn, K.G.; Menzes, M.; Mariano, R.R. (2001). Antagonism of Trichoderma sp. on Cladosporium herbarum and their enzymatic characterization. Braz. J. Microbiol. 32, 98-104.

4. Baker, R. (1988). Trichoderma spp. as plant-growth stimulants. Biotechnol. 7(2), 97-106.Benitez, T.; Rincon, A.M.; Limon, M.C.; Codon, A.C. (2004). Biocontrol mechanisms of Trichoderma strains. Int. Microbiol. 7(4), 249-260.

5. Bisset, J. (1991a). A revision of the genus Trichoderma. A. Infrageneric classification. Can. J. Bot. 69, 2357-2372.

6. Bisset, J. (1991b). A revision of the genus Trichoderma. B. Additional notes on section Longibrachiatum. Can. J. Bot. 69, 2418-2420.

7. Burgess, D.R.; Hepworth, G. (1996). Biocontrol of sclerotinia stem rot (Sclerotinia minor) in sunflower by seed treatment with Gliocladium virens. Plant Pathol. J. 45(3), 583-592.

8. Calistru, C.; Mclean, M.; Berjak, P. (1997). In vitro studies on the potential for biological control of Aspergillus flavus and Fusarium moniliforme by Trichoderma species. Mycopathol. 137, 115-24.

9. Davet, P.; Rouxel, F. (2000). Detection and Isolation of Soil Fungi. Science Publishers Inc, Enfield, USA.

10. Dennis, L.; Webster, J. (1971 a). Antagonistic properties of species groups of Trichoderma. I. Production of non-volatile antibiotics. Trans. Brith. Mycol. Soc. 57, 25-29.

11. Dennis, L.; Webster, J. (1971 b). Antagonistic properties of species groups of Trichoderma II. Production of non-volatile antibiotics. Trans. Br. Mycol. Soc. 57, 41-48.

12. Desai, S., Reddy, M.S., and Kloepper, J.W. (2002). Comprehensive testing of biological agents. In: Gnanamanickam, S.S. (Ed.). Biological Control of Crop Diseases. Marcel Dekker Inc, New York, USA, p. 387420 .

13. Gams,W.; Bisset, J. (1998). Morphology and identification of Trichoderma. In: Kubicek, C.P.; Harman, G.E. (eds). Trichoderma and Gliocladium Basic Biology, Taxonomy and Genetics. Taylor and Francis Ltd, London, UK, p. 57-74.

14. Gary, A.; Dirkse, E.; Sears, J.; Markworth, C. (2001). Volatile antimicrobials from Muscodor albus, a novel endophytic fungus. Microbiol. 147, 2943-2950.
15. Ellis, M.B. (1971). Dematiaceous Hyphomycetes. Common-wealth Mycological Institute, KEW, England.

16. Ershad, D. (1995). Fungi of Iran. Iranian Ministry of Agriculture, Tehran, Iran.

17. Harish, S.; Saravavakumar, D.; Radjacommar, R.; Ebenezar, E.G.; Seetharaman, K. (2007). Use of plant extracts and biocontrol agents for the management of brown spot disease in rice. Biocontrol 53(3), 555-567.

18. Harman, G.E. (2006). Overview of mechanisms and uses of Trichoderma spp. Phytopathol. 96, 190-194.

19. Hermosa, M.R., Grondona, I., Iturriaga, E.A., Diaz-Minguez, J.M., Castro, C., Monte, E., Garcia-Acha, I. 2000. Molecular characterization of biocontrol isolates of Trichoderma. Appl. Environ. Microbiol. 66:1890-1898.

20. International Rice Research Institute. (2002). Standard Evaluation System for Rice (SESR). Available at: http://www.irri.org.

21. Johnson, L.; Curl, E.; Bond, J.; Fribourg, H. (1959). Methods for Studying Soil Mycoflora. - Plant Disease Relationships. Burgess Publishing Company, Minneapolis.

22. Khosravi, V.; Zand, J.; Hedjaroude, GH-A.; Okhovvat, S.M. (2007). Seed-borne fungi of seed component in Mazandaran provinces. Abstract Book of $59^{\text {th }}$ International Symposium on Crop Protection, Iran, p. 295.

23. Kubicek, C.P.; Bisset, J.; Druzhinina, I.; Kullnig-Gradinger, C.; Szakacs, G. (2003). Genetic and metabolic diversity of Trichoderma: a case study on South-East Asian isolates. Fungal Genet. Biol. 38(3), 310-319.

24. Marco, J.L.; Inglis, M.C.; Felix, C.R. (2003). Production of hydrolytic enzymes by Trichoderma isolates with antagonistic activity against Crinipellis perniciosa, the causal agent of witches, broom of cocoa. Braz. J. Microbiol. 34(1), 148-54.

25. Naeimi, S.; Okhovvat, S.M.; Javan-Nikkhah, M.; Khosravi, V. (2008). Introducing Trichoderma spp. isolated from rice fields in Mazandaran Province. $18^{\text {th }}$ Iranian Plant Protection Congress, Hamedan, p. 626.

26. Nagamani, A.; Mew, T.W. (1987). Survey of Trichoderma species in rice field soils of the Philippines. Philippine Phytopathol, 23- 35.

27. Ou, S.H. (1985). Rice Diseases. Commonwealth Mycological Institute, London, USA.

28. Riddell, R.W. (1950). Permanent stained mycological preparation obtained by slide culture. Mycologia 42, 265-70.

29. Shovan, L.R.; Bhuiyan, M. K. A.; Begum, J. A.; Pervez, Z. (2008). In vitro Control of Colletotrichum dematium causing anthracnose of soybean by fungicides, plant extracts and Trichoderma harzianum. J. Sustain. Crop Prod. 3(3), 10-17.

30. Sivanesan, A. (1987). Graminicolous Species of Bipolaris, Curvularia, Drechslera, Exserohilum and Their Teleomorphs. Mycol. Pap. 158, 1261.

31. Torabi, M. (1984). Comparison few isolation methods of Drechslera oryzae from contaminated rice seeds Iran. J. of Plant Pathol. 20, 1-7.

32. Tsahouridou, P.C.; Thanassoulopoulosh, C.C. (2002). Proliferation of Trichoderma koningii in the tomato rhizosphere and the suppression of damping off by Sclerotium rolfsii. Soil Biol. Biochem. 34, 767-776. 
33. Vasudevan, P.; Kavitha, S.; Priyadarsini, V.B.; Babuje, L.; Gnanamanickam, S.S. (2002). Biological Control of Rice Diseases. In: Gnanamanickam S.S.(ed). Biological Control of Crop Diseases. Marcel Dekker, Inc, New York, Basel, p. 11-32.

34. White, T.J.; Bruns, T.; Lee, S.; Taylor, J. (1990). Amplification and direct sequencing of fungal ribosomal RNA genes for phylogenetics. In: Innes, M.H., Gelfand, D.H., Sninsky, J.J., White, T.J. (eds), PCR protocols.
Academic Press, San Diego, CA, pp. 315-322.

35. Zafari, D.; Zare, R.; Ershad, D.; Alizadeh, A. (2004). Three new species of Trichoderma for the mycoflora of Iran. Rostaniha 5, 159-169.

36. Zhang, C.; Druzhinina, I. S.; Kubicek, C. P.; XU, T. (2005). Trichoderma biodiversity in China: Evidence for a North to South distribution of species in East Asia. FEMS Microbiol. Lett., 251-257. 